\title{
VITAMIN D LEVELS AND VITAMIN D RECEPTOR GENE POLYMORPHISM IN MAJOR DEPRESSION
}

\author{
Merve Şahin Can ${ }^{1}$, Hayriye Baykan ${ }^{2}$, Özgür Baykan ${ }^{3}$, Nevin Erensoy ${ }^{4} \&$ Tunay Karlıdere $^{2}$ \\ ${ }^{1}$ Hopa State Hospital, Department of Psychiatry, Artvin, Turkey \\ ${ }^{2}$ Ballkesir University School of Medicine, Department of Psychiatry, Ballkesir, Turkey \\ ${ }^{3}$ Ataturk State Hospital, Biochemistry Laboratory, Ballkesir, Turkey \\ ${ }^{4}$ Ballkesir University School of Medicine, Department of Medical Biology, Ballkesir, Turkey
}

received: 24.1.2017;

revised: 20.4.2017;

accepted: 4.5.2017

\section{SUMMARY}

Background: The aim of this study is to evaluate vitamin D levels and rs2228570 (FokI) polymorphism of vitamin D in patients with established diagnosis of major depressive disorder in order to investigate the impact of vitamin $D$ levels and genetic polymorphisms on etiology and/or severity of the disease.

Subjects and methods: The study included 86 patients who were diagnosed with major depressive disorder in Hospital of Balıkesir University Faculty of Medicine, Department of Psychiatry, and 89 healthy volunteers with similar age, sex, education level and BMI. Psychiatric diagnosis was established by using Structured Clinical Interview for DSM-IV Axis I Disorders (SCID-I). For clinical evaluation, sociodemographic data form, Hamilton Depression Rating Scale, Hamilton Anxiety Scale were used. Blood samples were drawn after 12 hours of fasting from the patients volunteered and the control group who were given their informed consent for participation in the study. Vitamin D levels were determined by using the method of ECLIA (Electrochemiluminescent immunoassay). Genotype analysis was performed using the method of Polymerase Chain Reaction-Restriction Fragment Length Polymorphism (PCR-RFLP).

Results: In our study, median vitamin D levels (min-max) of the patient and control groups were $10.3 \mathrm{ng} / \mathrm{mL}$ (3.0-42.1) and 11.4 $n g / m L$ (3.0-38.8), respectively. Statistically significant differences as for vitamin D levels between groups were not detected $(p=0.729)$. Similiarly no statistically significant difference between groups in genotype distribution was observed $(p=0.396)$.

Conclusion: In conclusion, our findings do not support the relationship between depression, vitamin D levels and Fok 1 polymorphism of vitamin D receptor. To test these hypotheses in the light of literature we need further studies to be performed with large number of patients.

Key words: major depressive disorder (MDD) - vitamin D - VDR

\section{INTRODUCTION}

Major depressive disorder (MDD) is a mental disorder which causes serious functional loss lasting for at least two weeks, and characterized by depressed mood that is accompanied by loss of interest, pleasure, and depressive mood (Birliği 2013). The monoamine hypothesis, effect of stress, structural changes in the brain, the hypothalamus-pituitary axis abnormalities and neuroendocrine changes such as hypothyroidism have been studied as its pathophysiologic factors.

Vitamin D is a steroid hormone known for a long time for the effect on homeostasis of calcium and phosphorus. Its active metabolite $1.25(\mathrm{OH}) 2 \mathrm{D}$ has both genomic and non-genomic effects. Besides our well established knowledge about its effects on bone metabolism, presence of vitamin $\mathrm{D}$ receptor (VDR) and 1 alpha- hydroxylase enzyme, which converts $25(\mathrm{OH}) \mathrm{D}$ to $1.25(\mathrm{OH}) \mathrm{D} 2$, in the brain, has launched the explanation efforts of the relationship between brain development and neuropsychiatric disorders (Garcion et al. 2002). VDR has been identified in many tissues, including neurons and glial cells, and particularly prefrontal cortex, hippocampus, cingulate gyri, thalamus, and hypothalamus (Eyles et al. 2005). In addition, the mostly known active form of vitamin D, $1.25(\mathrm{OH}) 2$ $\mathrm{D} 3$, has been shown in cerebrospinal fluid (CSF) (Balabanova et al. 1984). Association of these areas with depression suggests the role of vitamin D in the pathophysiology of depression.

In recent studies, it was reported that vitamin D preserves the structure and concentration of neurons via detoxification mechanisms and regulating the synthesis of neurotrophins (Neveu et al. 1994a, Neveu et al. 1994b). Detoxification mechanisms includes inhibition of the inducible nitric oxide synthase synthesis and increases in glutathione levels (Garcion et al. 2002). In rats vitamin $\mathrm{D}$ has been shown to have protective effects against serotonin and dopamin depleting effects of neurotoxic doses of methamphetamine (Cass et al. 2006). In addition it has been reported that vitamin D increases expression of the tyrosine hydroxylase gene in adrenal medullary cells (Puchacz et al. 1996). This enzyme plays a role in the biosynthesis of cathecolamine as a rate-limiting enzyme.

Some studies have demonstrated that $25(\mathrm{OH}) \mathrm{D}$ which is thought to be a more reliable marker in the determination of vitamin D levels, is at a lower concen- 
tration in depressive patients relative to healthy controls (Eskandari et al. 2007, Hoogendijk et al. 2008, Jorde et al. 2006, Schneider et al. 2000). However some other studies do not support these finding (Herrán et al. 2000, Pan et al. 2009). This study is designed to estimate the effect of vitamin D levels and VDR gene polymorphism on patients with MDD in the light of literature information. Investigation of the place of vitamin D in the etiology of MDD, and development of new approaches is targeted with data to be obtained from this study.

\section{SUBJECTS AND METHODS}

\section{Selection of the Study Group}

The study included 86 major depressive disorder patients aged between 18-65 years who applied to Balikesir University Department of Psychiatry Clinic and 89 healthy volunteers who had similar age, gender, educational level and BMI.

Those who had important diseases which may affect vitamin D levels, those with chronic diseases, infectious diseases, users of drugs or supplements that may affect vitamin D levels, patients with previously known or concomitant diagnosis of dementia, patients in delirium, mental retardation, psychotic disorders, bipolar depression, alcohol and substance abuse, and pregnant women were excluded from the study.

This study was approved by the ethics committee of Balıkesir University School of Medicine, and all participants provided written informed consent.

\section{Laboratory Tests}

From healthy volunteers, and patients who gave their informed consent forms for the participation in the study blood samples were drawn after 12 hours of fasting and placed in a total of 3 tubes with EDTA. One tube of blood samples was centrifuged at $1300 \mathrm{Xg}$ and stored in the dark at $-20^{\circ} \mathrm{C}$ until analysis to determine $25(\mathrm{OH}) \mathrm{D}$ levels. Vitamin D levels were determined by using the method of ECLIA (Electrochemiluminescent immunoassay) via commercial kits (Roche Diagnostics, $\mathrm{GmBH}$, Germany). According to the manufacturer's data, for intraday and interday CV\% values for $19.9 \mathrm{ng} / \mathrm{ml}$ were $4.8 \%$ and $2.7 \%$ respectively, while for $38.3 \mathrm{ng} / \mathrm{ml}$ they were $6.2 \%$ and $3.7 \%$, respectively. Lower detection limit (LOD), and detection range of the test were reported as $3.0 \mathrm{ng} / \mathrm{mL}$, and 3-70 $\mathrm{ng} / \mathrm{ml}$, respectively.

The other two tubes with EDTA were reserved for the isolation of DNA. Salting out procedure was used for extracting DNA. Genotype analysis was determined by the method of Polymerase Chain Reaction-Restriction Fragment Length Polymorphism (PCR-RFLP).

\section{Clinical Measurement Scales}

Sociodemographic data form, Hamilton Depression Rating Scale, and Hamilton Anxiety Scale were applied for clinical assesment.

\section{Sociodemographic data Form}

Sociodemographic data form developed by us consists of the questions about socio-demographic characteristics such as age, sex, marital status, occupation and education level and the clinical features such as history of psychiatric disorders, alcohol, cigarette and drug use and menopausal status for women.

\section{Structured Interview Form for DSM-IVTR Axis 1 Disorders (SCID 1/Clinical Version)}

DSM-IV Axis I Disorders (SCID-I) is a structured scale consisting of 6 modules used to determine DSMIV Axis I disorders applied by the interviewer. It was developed by First et al in 1997 and Özkürkçügil et al have done reliability and validity studies of its Turkish version (First 1997, Özkürkçügil et al. 1999).

\section{Hamilton Depression Scale (HAM-D)}

It was published by Max Hamilton in 1960, and it is still widely used to measure the severity of depression. It contains 17 items which questions symptoms of depression within the previous week. Akdemir et al have done the Turkish version reliability and validity studies of its Turkish version (Akdemir et al. 1996, M 1960).

\section{Hamilton Anxiety Rating Scale (HAM-A)}

Hamilton Anxiety Rating Scale (HAM-A) is a semistructured question developed by Hamilton in the year 1959 to rate the severity of anxiety. It consists of 14 items which evaluate somatic, and psychic symptoms of anxiety. It was originally published by Max Hamilton in 1959 and Turkish version' reliability and validity study has been done by Yazıcı et al (Hamilton 1959, Yazıc1 1998).

\section{Statistical Analysis}

All statistical analyzes were performed using SPSS version 15.0 and Visual graphics (histogram, etc.) and appropriate statistical tests (Kolmogorov-Smirnov and Shapiro-Wilk) were used for evaluating normality of data. Student's t-test or Mann-Whitney U test was used for the comparison of independent two group means considering the normality of distribution. For assessing categorical data in cross- tables chi-square or Fisher's exact tests were used. Scale scores and the distribution of correlations between vitamin D levels were evaluated using Pearson or Spearman test. The effect of other independent variables on the possible role of genotype and D levels on the risk of depression was examined using logistic regression analysis and adjusted OR values were calculated. In all statistical analysis, level of statistical significance was defined as $p$ value of less than 0.05 . 


\section{RESULTS}

When sociodemographic data of the patient, and the control groups were compared as for sociodemographic data, age, gender, BMI, smoking, and alcohol use, any statistically significant intergroup difference was not seen (Table 1).

Besides any statistically significant difference was not observed between education levels of the participants in the patient, and control groups. In both groups married participants were more numerous, but without any statistically significant intergroup difference between groups $(\mathrm{p}=0.376)$

\section{Clinical Evaluation Scales}

The median (min-max) value of HAM-D scores was 21 (10-32) for patients and 2 (0-13) for the control group. The difference between the 2 groups was statistically, and highly significant $(\mathrm{p}<0.001)$. The median (min$\max$ ) value of HAM-A scores was 16 (1-31) for patients and $3(0-15)$ for the control group. Similarly, the difference between the 2 groups was statistically, and highly significant $(\mathrm{p}<0.001)$ for HAM-A scores. A strong positive correlation was found between HAM-A and HAM-D scores $(\mathrm{r}=0.864, \mathrm{p}<0.001)$ (Table 2).

\section{Vitamin D levels}

Vitamin D levels median (min-max) values of the patient and the control groups were $10.3 \mathrm{ng} / \mathrm{mL}$ (3.042.1) and $11.4 \mathrm{ng} / \mathrm{mL}(3.0-38.8)$ respectively (Figure 1). Statistically significant difference was not detected between the groups as for vitamin D levels $(p=0.729)$.
When vitamin D levels were evaluated in $82 \%$ of the control group and in \% 77.9 of patients vitamin D levels were less than $20 \mathrm{ng} / \mathrm{mL}$ which is considered the reference value for vitamin $D$ insufficiency $(p=0.496)$ (Risteli 2012). Still a statistically significant difference was not seen between the patient, and the control groups regarding vitamin D insufficiency.

When we evaluated the relationship between levels of vitamin D and clinical rating scales, there was no correlation between vitamin D levels and scale scores. Median (min-max) value of vitamin D levels of the patients who experienced their first episode of depression was 11.2 (3.0-38.8), 9.9 (3.4-42.2) in patients who suffered from recurrent attacks and 11.4 (3.0-38.7) in the control group. Statistically significant difference was not detected between frequency of attacks and vitamin D levels ( $\mathrm{p}=0.546$ ) (Figure 1).

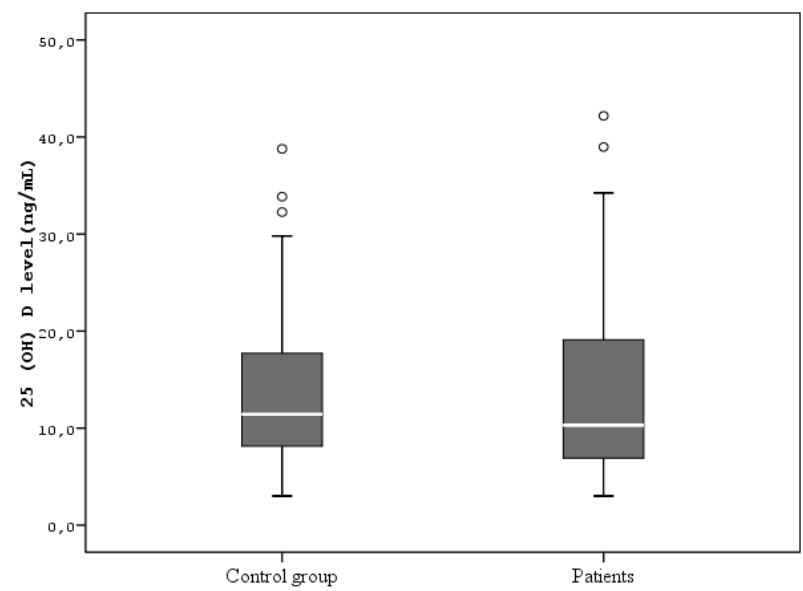

Figure 1. Vitamin D levels of the study participants

Table 1. Comparison of sociodemographic data

\begin{tabular}{lccc}
\hline & MDD $(\mathrm{n}=86)$ & Control $(\mathrm{n}=89)$ & P value \\
\hline Age (Mean \pm SD years) & & & 0.774 \\
$\quad$ Women & $37.8 \pm 12.5$ & $37.3 \pm 12.2$ & 0.664 \\
$\quad$ Men & $37.6 \pm 12.4$ & $39.9 \pm 11.7$ & 0.065 \\
BMI $(\mathrm{kg} / \mathrm{m} 2)$ & $26.6 \pm 7.2$ & $24.9 \pm 3.9$ & 0.45 \\
Gender & & & \\
$\quad$ Female & $\mathrm{n}=75$ & $\mathrm{n}=74$ & 0.314 \\
$\quad$ Male & $\mathrm{n}=11$ & $\mathrm{n}=15$ & 0.272 \\
Current smoker & $\mathrm{n}=24$ & $\mathrm{n}=19$ & $\mathrm{n}=2$ \\
Regular alcohol user & $\mathrm{n}=5$ & & \\
\hline
\end{tabular}

Table 2. HAM-D and HAM-A scores of the study participants

\begin{tabular}{lccc} 
& $\begin{array}{c}\text { MDD } \\
\text { Median (min-max) }\end{array}$ & $\begin{array}{c}\text { Control } \\
\text { Median (min-maz) }\end{array}$ & P value \\
\hline HAM-D & $21(10-32)$ & $2(0-13)$ & $<0.001$ \\
HAM-A & $16(1-31)$ & $3(0-15)$ & $<0.001$ \\
\hline
\end{tabular}

Table 3. FokI polymorphism genotype distribution

\begin{tabular}{lcccc}
\hline VDR gene & Patient $(\mathrm{n}=86)$ & Control $(\mathrm{n}=89)$ & OR $(95 \% \mathrm{GA})$ & $\mathrm{p}$ \\
\hline FF & $32(43.8 \%)$ & $41(56.2 \%)$ & $0.694^{\mathrm{a}}(0.38-1.27)$ & $0.236^{\mathrm{a}}$ \\
Ff & $46(51.7 \%)$ & $43(48.3 \%)$ & $1.23^{\mathrm{b}}(0.68-2.23)$ & $0.494^{\mathrm{b}}$ \\
ff & $8(61.5 \%)$ & $5(38.5 \%)$ & $1.723^{\mathrm{c}}(0.54-5.50)$ & $0.358^{\mathrm{c}}$ \\
\hline
\end{tabular}

${ }^{\mathrm{a}} \mathrm{FF}<>\mathrm{Ff}+\mathrm{ff} ; \quad{ }^{\mathrm{b}} \mathrm{Ff}<>\mathrm{FF}+\mathrm{ff} ; \quad{ }^{\mathrm{c}} \mathrm{ff}<>\mathrm{FF}+\mathrm{Ff}$ 
In our study, we found no statistically significant difference between groups as for FokI polymorphism genotype distribution $(\mathrm{p}=0.396)$. While $90.7 \%$ of patients and $94.4 \%$ of control group had $\mathrm{F}$ allele while frequency of $\mathrm{f}$ alleles had been seen in $62.8 \%$ of the patients and $53.9 \%$ of the control subjects (Table 3 ).

\section{DISCUSSION}

Vitamin D deficiency has been seen in many people worldwide so it is defined as a global problem (Bhimani 2012). In Saudi Arabia, United Arab Emirates, Australia and India vitamin D levels were reported to be below 20 $\mathrm{ng} / \mathrm{ml}$ in $30-50 \%$ in children and adultsm (Fuleihan et al. 2001, Marwaha et al. 2005, McGrath et al. 2001, Sedrani 1984).

In recent years the relationship between vitamin $\mathrm{D}$ levels and many diseases have been frequently discussed. There is increasing number of studies trying to explain mainly the relationship between vitamin $D$, psychotic disorders and major depressive disorders in pschiatry. Higher incidence of schizophrenia among individuals born in the winter and spring months, increase in disease incidence in cold climates and the relationship between maternal nutritional deficiency and schizophrenia suggest the relationship between schizophrenia and low vitamin D levels (McGrath 1999). In Northern Finland, a follow-up study with 9114 participants showed that vitamin D supplementation during the first year of life is associated with a reduction in the incidence schizophrenia in men (McGrath et al. 2004). In a small scale cohort study in third trimester maternal $25(\mathrm{OH}) \mathrm{D}$ levels were analyzed, the study participants were followed up until the age of 30 and the investigators reported that levels of maternal vitamin D may be associated with an increased risk of schizophrenia (29 vs 46\% ) (Eyles et al. 2003). Similarly, Zeng and colleagues also evaluated 52 patients and found that $28.8 \%$ of the patients in the study had low vitamin $\mathrm{D}$ levels and no difference had been seen between major psychiatric diagnoses (Zeng et al. 2016).

Studies on depression have yielded different results. As is known, depression demonstrates seasonal specialties, especially in the winter months with phototherapy improved treatment responses are achieved (Rosenthal et al. 1988). In cases of low vitamin D levels, parathyroid hormone (PTH) levels increase and hyperparathyroidism has been reported often with depressive symptoms (Özen \& Haspolat 2003). JoBorn et al. mentioned that in primary hyperparathyroidism, and mild hypercalcemia, depression, anxiety and cognitive complaints are frequently seen, and and one year after the parathyroid surgery, improvements in psychiatric symptoms were observed (Jobom et al. 1989).McCue et al evaluated 107 pschiatric patients and found vitamin D levels below $20 \mathrm{ng} / \mathrm{ml}$ in \% 52.3 of the patients while they hadn't observed any association between psychiatric diagnosis with vitamin $\mathrm{D}$ levels (McCue et al. 2012). Vitamin D deficiency has been associated with deterioration in cognitive function and depressive mood particularly in elder age (Hoogendijk et al. 2008, Wilkins et al. 2006). Milaneschi and his colleagues found that low baseline vitamin D is associated with an increased probability in developing depressive mood after 6 years of follow-up in people above 65 years of age. Especially in women this relationship between vitamin D levels, and depression stronger (Milaneschi et al. 2010). In another study Schneider et al. compared 34 schizophrenic, 25 depressive and 30 alcohol-dependent patients with healthy controls, and lower levels of 25 $(\mathrm{OH}) \mathrm{D}$ and $1.25(\mathrm{OH}) \mathrm{D}$ were found in patients. The authors thought that these lower levels might be associated with low socioeconomic status and unhealthy eating habits (Schneider et al. 2000). In a large population study carried out by Ganji and colleagues people who had active depressive symptoms had lower vitamin $\mathrm{D}$ levels than those without with an incidence rate of 8.4\% (Ganji et al. 2010). In 2014 Yilmaz et al found negative correlation between vitamin D levels and Beck Depression Inventory scores in premenopausal women (Yilmaz et al. 2014). However, similar to our study, in 2010, Zhao et al reported lack of any relationship between vitamin $\mathrm{D}$ levels and major or minor depressive disorders (Zhao et al. 2010).

There are many studies concerning vitamin D supplements in depression with inconsistent results. Lansdowne and Provost provided vitamin D support in winter months to healthy people and indicated an increase in positive affect scores (Lansdowne \& Provost 1998). Dumville and his collegues reported that during winter months, receiving daily doses of 800 IU vitamin $\mathrm{D}$ made no changes in mental well-being in women over 70 years of age (Dumville et al. 2006). Also, Haris and his collegues reported the results of 1 year of vitamin D supplementation to 125 women with seasonal affect swings had not exerted positive effects on these changes (Harris \& Dawson-Hughes 1993). Khoraminya et al treated 21 major depressive disorder patients, with 20 mg of fluoxetine and $1500 \mathrm{IU}$ of vitamin D combination for 8 weeks and 21 patients only with fluoxetine in a double-blind placebo-controlled randomized trial. They indicated that combination therapy was superior to fluoxetine treatment after 4 weeks of study (Khoraminya et al. 2013). In 2014 Spedding reported that vitamin D supplementation provided statistically significant improvement in depression after excluding biological flaws in a meta-analysis of 15 randomized controlled trials. Biological flaws were listed as, using inappropriate supplements, decrease in vitamin D levels after vitamin supplementation, taking ineffective doses of vitamin D, failure to measure baseline levels of vitamin $\mathrm{D}$, and in cases with deficient levels of vitamin D (Spedding 2014).

The results of polymorphism analysis are different in each community so it is adequate to calculate VDR genotype frequencies for each population. The only VDR polymorphism that changes the structure of receptor is a polymorphism in exon 2 and Fok I restriction 
enzyme is used for its determination (Uitterlinden et al. 2004). In Turkey, in a study of 100 healthy individuals realized in the year 2002, VDR alleles (F: 0.73, f: 0.27) and VDR genotype frequencies (FF: 55\%, Ff: 36\%, FF: $9 \%$ ) were detected, as indicated (Dayangaç 2002). In our study, we found similar results, however any difference was not observed in genotype distribution between patients and controls.

Experimentally, VDR mutant mice showed deteriorated social behavior, increased anxiety-like behavior and abnormal grooming. But Kalueff et al could not determine depression-like behaviour in these mice (Kalueff et al. 2004). In human studies; Yan and his collegues reported lack of any relationship between VDR variants and schizophrenia in DNA analysis of 192 patients (Yan et al. 2005). Ahmadi et al reported that ff genotype was more frequent in patients with bipolar disorder and is associated with decreased in D1 dopamine receptor gene expression (Ahmadi et al. 2012). In another study, Kuningas reported that individuals over 85 years of age who had BsmI and TaqI polymorphisms were more sensitive to age-related cognitive deterioration, while the ApaI polymorphism was protective against the effect of deterioration and depressive symptoms (Kuningas et al. 2009). Similar to our study, in their study any relationship was not observed between depressive symptoms and FokI polymorphism. Also Özdolap and colleagues could not find any significant differences between patients with fibromyalgia which is often accompanied by depression and control group regarding both vitamin levels and allele frequencies (Özdolap 2012).

Our study has some limitations, and strengths as well. Measurement of $25(\mathrm{OH}) \mathrm{D}$ as the best indicator of vitamin D level, diagnosis of depression by clinician and applying clinical scores by experienced physicians, exclusion of confounding factors that may affect vitamin D levels such as age, physical activity, chronic illness, cancer, cardiovascular system pathologies, autoimmune diseases are the strenghts of our study. Although the incidence of depression is higher in women in the community, since number of female participants in our study is more than three times the number of men so it is difficult to generalize results to general population.

\section{CONCLUSION}

Our results do not support the hypothesis that vitamin D levels and Fok1 polymorphism of VDR gene play a role in the etiology of depressive disorder. We think that that relationship between depression and vitamin D deficiency is not a cause-effect relationship, but two events seem to trigger each other. Some lifestyle changes, such as reduced food intake, or reduced time of sun exposure because of psychomotor retardation in depression may lead to vitamin D deficiency. There is evidence in literature that vitamin D enhances positive mood. However, for precise determination of this phenomenon, placebo-controlled studies should be performed where priorly baseline vitamin D levels of the patients followed up with major depressive disorder should be measured, and given vitamin D supplements to optimize their vitamin D levels.

\section{Acknowledgements:}

This research was supported by Balıkesir University, Scientific Research Project.

Conflict of interest: None to declare.

\section{Contribution of individual authors:}

Merve Şahin Can \& Hayriye Baykan participated in the design of the study.

All authors participate in literature search and analyses, interpretation of data and writing of the manuscript.

\section{References}

1. Ahmadi S, Mirzaei K, Hossein-Nezhad A, Shariati G: Vitamin $D$ receptor FokI genotype may modify the susceptibility to schizophrenia and bipolar mood disorder by regulation of dopamine D1 receptor gene expression. Minerva medica 2012; 103:383-391.

2. Akdemir A, Örsel S, Dă̆ İ, Türkçapar H, İscan N, Özbay $H:$ Hamilton Depresyon Derecelendirme Ölçeği (HDDÖ)'nin geçerliği, güvenirliği ve klinikte kullanımı. Psikiyatri Psikoloji Psikofarmakoloji Dergisi 1996; 4:251259.

3. Balabanova S, Richter H-P, Antoniadis G, Homoki J, Kremmer N, Hanle J, Teller W: 25-Hydroxyvitamin D, 24, 25-dihydroxyvitamin $D$ and 1, 25-dihydroxyvitamin $D$ in human cerebrospinal fluid. Klinische Wochenschrift 1984: 62:1086-1090.

4. Bhimani MM: Vitamin D: does it play a role in psychiatry. Journal of the Pakistan Medical Association 2012; 62:181.

5. Birliği AP: Ruhsal Bozuklukların Tanısal ve Sayımsal Elkitabı (DSM-5) Tanı Ölçütleri Başvuru Elkitabı. Hekimler Yayın Birliği, Ankara, 2013.

6. Cass WA, Smith MP, Peters LE: Calcitriol Protects against the Dopamine and Serotonin Depleting Effects of Neurotoxic Doses of Methamphetamine. Annals of the New York Academy of Sciences 2006; 1074:261-271.

7. Dayangaç D, ÖE, Özbaş Gerçeker F, Coşkun T, Erdem Yurter H: Sağllkll Türk Populasyonunda Vitamin D Reseptör (VDR) Gen Polimorfizm Analizi. Türk Biyokimya Dergisi 2002; 27:11-16.

8. Dumville J, Miles J, Porthouse J, Cockayne S: Can vitamin D supplementation prevent winter-time blues? A randomised trial among older women. The journal of nutrition, health \& aging 2006: 10:151.

9. Eskandari F, Martinez PE, Torvik S, Phillips TM, Sternberg EM, Mistry S, Ronsaville D, Wesley R, Toomey $C$, Sebring NG: Low bone mass in premenopausal women with depression. Archives of Internal Medicine 2007; 167:2329-2336.

10. Eyles D, Brown J, Mackay-Sim A, McGrath J, Feron F: Vitamin D 3 and brain development. Neuroscience 2003; 118:641-653. 
11. Eyles DW, Smith S, Kinobe R, Hewison M, McGrath JJ: Distribution of the vitamin $D$ receptor and $1 \alpha$-hydroxylase in human brain. Journal of chemical neuroanatomy 2005; 29:21-30

12. First $M B$, SR, Gibbon M, Williams JBW: Structured Clinical Interview for DSM-IV Axis I Disorders, Clinical Version (SCID/CV). American Pcychiatric Pres, Washington, 1997.

13. Fuleihan GE-H, Nabulsi M, Choucair M, Salamoun M, Shahine CH, Kizirian A, Tannous R: Hypovitaminosis D in healthy schoolchildren. Pediatrics 2001; 107:e53-e53.

14. Ganji V, Milone C, Cody MM, McCarty F, Wang YT: Serum vitamin $D$ concentrations are related to depression in young adult US population: the Third National Health and Nutrition Examination Survey. International Archives of Medicine 2010; 3:1.

15. Garcion E, Wion-Barbot N, Montero-Menei CN, Berger F, Wion D: New clues about vitamin $D$ functions in the nervous system. Trends in Endocrinology \& Metabolism 2002: 13:100-105.

16. Hamilton M: The assessment of anxiety states by rating. British journal of medical psychology 1959; 32:50-55.

17. Harris S, Dawson-Hughes B: Seasonal mood changes in 250 normal women. Psychiatry research 1993; 49:77-87.

18. Herrán A, Amado JA, García-Unzueta MT, VázquezBarquero JL, Perera L, González-Macías J: Increased bone remodeling in first-episode major depressive disorder. Psychosomatic medicine 2000; 62:779-782.

19. Hoogendijk WJ, Lips P, Dik MG, Deeg DJ, Beekman AT, Penninx BW: Depression is associated with decreased 25hydroxyvitamin $D$ and increased parathyroid hormone levels in older adults. Archives of General Psychiatry 2008; 65:508-512.

20. Jobom C, Hetta J, Lind L, Rastad J: Self-rated psychiatric symptoms in patients operated on because of primary hiperparathyroidism and in patients with long-standing mild hypercalcemia, 1989

21. Jorde R, Waterloo K, Saleh F, Haug E, Svartberg J: Neuropsychological function in relation to serum parathyroid hormone and serum 25-hydroxyvitamin $D$ levels. Journal of neurology 2006; 253:464-470.

22. Kalueff AV, Lou Y-R, Laaksi I, Tuohimaa P: Increased anxiety in mice lacking vitamin $D$ receptor gene. Neuroreport 2004; 15:1271-1274.

23. Khoraminya N, Tehrani-Doost M, Jazayeri S, Hosseini A, Djazayery A: Therapeutic effects of vitamin $D$ as adjunctive therapy to fluoxetine in patients with major depressive disorder. Australian and New Zealand Journal of Psychiatry 2013; 47:271-275.

24. Kuningas M, Mooijaart SP, Jolles J, Slagboom PE, Westendorp $R G$, van Heemst $D$ : VDR gene variants associate with cognitive function and depressive symptoms in old age. Neurobiology of aging 2009; 30:466-473.

25. Lansdowne AT, Provost SC: Vitamin D3 enhances mood in healthy subjects during winter. Psychopharmacology 1998; 135:319-323.

26. $M$ H: A rating scale for depression. Journal of neurology, neurosurgery, and psychiatry 1960; 23:56-62.

27. Marwaha RK, Tandon N, Reddy DRH, Aggarwal R, Singh $R$, Sawhney RC, Saluja B, Ganie MA, Singh S: Vitamin D and bone mineral density status of healthy schoolchildren in northern India. The American journal of clinical nutrition 2005; 82:477-482.
28. McCue RE, Charles RA, Orendain G, Joseph MD, Abanishe JO: Vitamin D deficiency among psychiatric inpatients. Prim Care Companion CNS Disord, 2012; 14.

29. McGrath J: Hypothesis: is low prenatal vitamin D a riskmodifying factor for schizophrenia? Schizophrenia research 1999; 40:173-177.

30. McGrath J, Kimlin MG, Saha S, Eyles D, Parisi A: Vitamin $D$ insufficiency in south-east Queensland. Medical Journal of Australia 2001; 174:150-150.

31. McGrath J, Saari K, Hakko H, Jokelainen J, Jones P, Järvelin M-R, Chant $D$, Isohanni M: Vitamin $D$ supplementation during the first year of life and risk of schizophrenia: a Finnish birth cohort study. Schizophrenia research 2004; 67:237-245.

32. Milaneschi Y, Shardell M, Corsi AM, Vazzana R, Bandinelli S, Guralnik JM, Ferrucci L: Serum 25hydroxyvitamin $D$ and depressive symptoms in older women and men. The Journal of Clinical Endocrinology \& Metabolism 2010; 95:3225-3233.

33. Neveu I, Naveilhan P, Baudet C, Brachet P, Metsis M: 1, 25-dihydroxyvitamin D3 regulates NT-3, NT-4 but not BDNF mRNA in astrocytes. Neuroreport 1994a; 6:124-126.

34. Neveu I, Naveilhan P, Baudet C, Wion D, De Luca HF, Brachet $P:$ 1, 25-dihydroxyvitamin $D 3$ regulates the synthesis of nerve growth factor in primary cultures of glial cells. Molecular Brain Research 1994b; 24:70-76.

35. Özdolap Ş, D. A, Maraşlı E: Fibromiyalji tanılı hastalarda vitD reseptörü gen polimorfizmi siklı̆̆ının belirlenmesi, 2012.

36. Özen Ş, Haspolat K: D Vitamini, Kalsiyum, Kemik Metabolizması ve Psikiyatrik Bozukluklar. Klinik Psikiyatri 2003; 6:102-113.

37. Özkürkçügil A, Aydemir Ö, Yıldız M, Esen Danacı A, Köroğlu IV E: DSM-IV Eksen I bozuklukları için yapılandırılmış klinik görüşmenin Türkçe'ye uyarlanması ve güvenilirlik çalışması. İlaç ve Tedavi Dergisi 1999; 12:233-236

38. Pan A, Lu L, Franco OH, Yu Z, Li H, Lin X: Association between depressive symptoms and 25-hydroxyvitamin $D$ in middle-aged and elderly Chinese. Journal of affective disorders 2009; 118:240-243.

39. Puchacz E, Stumpf WE, Stachowiak EK, Stachowiak MK: Vitamin $D$ increases expression of the tyrosine hydroxylase gene in adrenal medullary cells. Molecular Brain Research 1996; 36:193-196.

40. Risteli J KM, R. L: Textbook of Clinical Chemistry and Molecular Diagnostics, 5 ed. Elselvier, Missouri, 2012.

41. Rosenthal NE, Sack DA, Skwerer RG, Jacobsen FM, Wehr TA: Phototherapy for seasonal affective disorder. Journal of Biological Rhythms, 1988.

42. Schneider B, Weber B, Frensch A, Stein J, Fritze J: Vitamin $D$ in schizophrenia, major depression and alcoholism. Journal of neural transmission 2000; 107:839-842.

43. Sedrani SH: Low 25-hydroxyvitamin D and normal serum calcium concentrations in Saudi Arabia: Riyadh region. Annals of nutrition and metabolism 1984; 28:181-185.

44. Spedding S: Vitamin $D$ and depression: a systematic review and meta-analysis comparing studies with and without biological flaws. Nutrients 2014; 6:1501-1518.

45. Uitterlinden AG, Fang $Y$, van Meurs JB, Pols HA, van Leeuwen JP: Genetics and biology of vitamin D receptor polymorphisms. Gene 2004; 338:143-156. 
46. Wilkins CH, Sheline YI, Roe CM, Birge SJ, Morris JC: Vitamin $D$ deficiency is associated with low mood and worse cognitive performance in older adults. The American journal of geriatric psychiatry 2006; 14:10321040.

47. Yan J, Feng J, Craddock N, Jones IR, Cook EH, Goldman D, Heston LL, Chen J, Burkhart P, Li W: Vitamin D receptor variants in 192 patients with schizophrenia and other psychiatric diseases. Neuroscience letters 2005; 380:37-41.

48. Yazıcı MK, D. B, Tanrıverdi N, Karaağaoğlu E, Yolaç P: Hamilton Anksiyete Değerlendirme Ölçeği, derecelendiriciler arası güvenilirlik ve geçerlilik çalışması. Türkiye Psikiyatri Dergisi 1998; 9:114-117.
49. Yilmaz H, Bodur S, Karaca G: The association between vitamin $D$ level and chronic pain and depression in premenopausal women/Premenopozal eriskin kadinlarda vitamin D duzeyi ile kronik agri ve depresyon arasindaki iliski. Turkish Journal of Physical Medicine and Rehabilitation 2014; 60:121-126.

50. Zeng Q, Dellenbaugh T, Maldonado M, Moon J, Hornstra, $R$ : Vitamin $D$ status of psychiatric inpatients at a community teaching hospital in the Midwest. Nordic journal of psychiatry 2016; 70:208-214.

51. Zhao G, Ford ES, Li C, Balluz LS: No associations between serum concentrations of 25-hydroxyvitamin D and parathyroid hormone and depression among US adults. British Journal of Nutrition 2010; 104:1696-1702.

\section{Correspondence:}

Merve Sahin Can, MD

Hopa State Hospital, Department of Psychiatry

Artvin, Turkey

E-mail: mervesahin86@hotmail.com 